\title{
Is routine early invasive management of non-ST-segment elevation myocardial infarction beneficial in elderly patients?
}

Bach RG, Cannon CP, Weintraub WS, DiBasttiste PM, Demopoulos LA, Anderson HV, et al. The effect of routine, early invasive management on outcome for elderly patients with non-STsegment elevation acute coronary syndromes. Ann Intern Med 2004;141:186-95.

Background: The advantages of early invasive management (cardiac catheterization or revascularization) of non-ST-segment myocardial infarction (nonSTEMI) over a conservative approach (in-hospital observation and predischarge stress testing, with catheterization reserved only for spontaneous or inducible high-risk ischemia) remain controversial. Initial trials suggested no superiority; ${ }^{1,2}$ however, recent trials have shown improved quality of life, fewer reinfarctions and fewer ische₹ mia-related hospital readmis学 sions as well as a suggested reduction in mortality with the early invasive strategy. ${ }^{3,4}$ Inconsistencies between the initial and recent trials have been attributed to the use of thienopyridines, glycoprotein IIb/IIIa in- hibitors and coronary artery stenting in the more recent trials. Few studies have examined whether these advantages are generalizable to elderly patients - a high-risk subgroup that accounts for the majority of patients with non-STEMI.

Design: This international randomized controlled trial (TACTICS-TIMI 18) enrolled 2220 patients who had clinical features consistent with nonSTEMI. Patients were excluded if they had bleeding disorders, cerebrovascular disease, congestive heart failure, renal dysfunction or other important systemic disease or if they were receiving long-term therapy with ticlopidine, clopidogrel or warfarin. All of the participants received ASA, un- fractionated heparin and tirofiban and were randomly assigned to either the early invasive strategy or the early conservative therapy. End points included death, nonfatal myocardial infarction, readmission because of acute coronary syndrome, bleeding and stroke.

Results: Almost half (43\%) of the cohort was 65 years of age or older; these patients constituted a higher risk group than the younger patients, as noted by the distribution of the TIMI risk scores (score of 3 or greater in $90.6 \%$ of the elderly patients $\mathrm{v}$. $63 \%$ of the younger patients, $p<$ 0.001). Among the patients in the early invasive strategy group, $96 \%$ and $64 \%$ received coronary angiography and revascularization (percutaneous transluminal coronary angioplasty or coronary artery bypass surgery) respectively, and did so within 48 hours after hospital presentation. In contrast, the rates of coronary angiography and revascularization by 6 months from initial

Table 1: Clinical outcomes associated with the early invasive strategy compared with the conservative strategy in younger and older patients*

\begin{tabular}{|c|c|c|c|c|c|c|}
\hline \multirow[b]{2}{*}{ Outcome } & \multicolumn{3}{|c|}{ Patients $<65$ yr old } & \multicolumn{3}{|c|}{ Patients $\geq 65$ yr old } \\
\hline & $\begin{array}{c}\text { Invasive } \\
\text { strategy } \\
(n=623), \%\end{array}$ & $\begin{array}{c}\text { Conservative } \\
\text { strategy } \\
(n=635), \%\end{array}$ & $\begin{array}{l}\text { Odds ratio } \\
(95 \% \mathrm{Cl})\end{array}$ & $\begin{array}{c}\text { Invasive } \\
\text { strategy } \\
(n=491), \%\end{array}$ & $\begin{array}{l}\text { Conservative } \\
\text { strategy } \\
(n=471), \%\end{array}$ & $\begin{array}{c}\text { Odds ratio } \\
(95 \% \mathrm{Cl})\end{array}$ \\
\hline \multicolumn{7}{|l|}{$30 \mathrm{~d}$} \\
\hline Death & 1.1 & 0.6 & $1.79(0.52-6.15)$ & 3.7 & 3.0 & $1.24(0.61-2.53)$ \\
\hline MI & 2.9 & 4.3 & $0.67(0.37-1.23)$ & 3.3 & 7.9 & $0.40(0.22-0.72)$ \\
\hline Death or MI & 3.9 & 4.9 & $0.78(0.45-1.35)$ & 5.7 & 9.8 & $0.56(0.34-0.91)$ \\
\hline Rehospitalization for ACS & 3.9 & 5.2 & $0.73(0.43-1.25)$ & 2.9 & 5.9 & $0.46(0.24-0.89)$ \\
\hline Death, MI or rehospitalization for ACS & 6.7 & 8.5 & $0.78(0.51-1.18)$ & 8.2 & 13.2 & $0.59(0.38-0.89)$ \\
\hline \multicolumn{7}{|l|}{$6 \mathrm{mo}$} \\
\hline Death & 1.8 & 1.7 & $1.02(0.44-2.37)$ & 5.3 & 5.9 & $0.88(0.51-1.53)$ \\
\hline MI & 4.7 & 4.9 & $0.95(0.57-1.60)$ & 4.9 & 9.6 & $0.49(0.29-0.81)$ \\
\hline Death or MI & 6.1 & 6.5 & $0.94(0.60-1.48)$ & 8.8 & 13.6 & $0.61(0.41-0.92)$ \\
\hline Rehospitalization for ACS & 11.7 & 14.2 & $0.80(0.58-1.12)$ & 10.2 & 13.2 & $0.75(0.50-1.11)$ \\
\hline Death, $\mathrm{MI}$ or rehospitalization for ACS & 14.9 & 17.8 & $0.81(0.60-1.09)$ & 17.1 & 21.7 & $0.75(0.54-1.03)$ \\
\hline
\end{tabular}

Note: $\mathrm{ACS}=$ acute coronary syndrome, $\mathrm{MI}=$ myocardial infarction

*Reproduced, with permission, from Bach RG, Cannon CP, Weintraub WS, DiBasttiste PM, Demopoulos LA, Anderson HV, et al. The effect of routine, early invasive management on outcome for elderly patients with non-ST-segment elevation acute coronary syndromes. Ann Intern Med 2004;141:186-95. 
presentation were $53 \%$ and $38 \%$ in the conservative therapy group. Outcomes at 30 days and 6 months are shown in Table 1 . Among the elderly patients, a significant absolute risk reduction of $4.6 \%$ (relative risk reduction [RRR] 58\%) and 3\% (RRR $48 \%$ ) in nonfatal $\mathrm{MI}$ and readmission because of acute coronary syndrome, respectively, was shown at 30 days; similar findings were noted at 6 months. Rates of death were similar in both groups.

Commentary: This study shows that elderly patients may derive benefit from an early invasive strategy for the management of non-STEMI. Although no mortality difference was observed between the 2 groups, there were 47 fewer nonfatal MIs over a 6-month period for every 1000 patients treated with an invasive strategy. The study's strengths include its highquality prospective design, the large sample and the relevant end points. Limitations include lack of details on other medical interventions used and the exclusion of elderly patients with significant comorbidities.
Practice implications: This study is the first to explore the benefit of an early invasive strategy involving the routine use of thienopyridines, glycoprotein IIb/IIIa inhibitors and coronary stenting among elderly patients with nonSTEMI. The findings are consistent with those of recent trials showing improved outcomes associated with an invasive approach for nonSTEMI. ${ }^{3,4}$ Although the absolute benefits in terms of the prevention of nonfatal MI and hospital readmission are impressive, enthusiasm must be tempered against uncertainty over the long-term sustainability of such benefits, the costeffectiveness of an invasive treatment approach and its applicability in actual practice, where the increased prevalence of comorbidities may mitigate any benefits derived from such an approach. Moreover, capacity constraints and process delays in our health care system may impede the ability to deliver timely interventions and may erode the benefits associated with an early invasive strategy.
Sheldon M. Singh

David A. Alter

Department of Medicine

Sunnybrook and Women's College

Health Sciences Centre

University of Toronto

Toronto, Ont.

\section{References}

1. Anderson HV, Cannon CP, Stone $\mathrm{PH}$, Williams DO, McCabe CH, Knatterud GL, et al. One-year results of the Thrombolysis in Myocardial Infarction (TIMI) IIIB clinical trial. A randomized comparison of tissue-type plasminogen activator versus placebo and early invasive versus early conservative strategies in unstable angina and non-Q wave myocardial infarction. $\mathcal{F}$ Am Coll Cardiol 1995;26:1643-50.

2. Boden WE, O'Rourke RA, Crawford MH, Blaustein AS, Deedwania PC, Zoble RG, et al. Outcomes in patients with acute non-Q-wave myocardial infarction randomly assigned to an invasive as compared with a conservative management strategy. Veterans Affairs Non-Q-Wave Infarction Strategies in Hospital (VANQWISH) Trial Investigators [published erratum appears in $N$ Engl 7 Med 1998;339(15):1091]. N Engl 7 Med 1998;338:1785-92.

3. Janzon M, Levin LA, Swahn E. Invasive treatment in unstable coronary artery disease promotes health related quality of life: results from the FRISC II trial. Am Heart 7 2004;148:114-21.

4. Bavry AA, Kumbhani DJ, Quiroz R, Ramchandani SR, Kenchaiah S, Antman EM. Invasive therapy along with glycoprotein IIb/IIIa inhibitors and intracoronary stents improves survival in non-ST-segment elevation acute coronary syndromes: a metaanalysis and review of the literature. Am 7 Cardiol 2004;93:830-5.

\section{Books Received}

Amar MB. Cannabis. Montréal: Drogues, santé et société; 2004. 539 pp. \$25.00 ISSN 1703-8839

Anlyan WG. Metamorphoses: memoirs of a life in medicine. Durham (NC): Duke University Press; 2004. 229 pp. \$29.95 (cloth) ISBN 0-8223-3378-3

Armstrong-Coster A. Living and dying with cancer. New York: Cambridge University Press; 2004. 194 pp. US\$65.00 (cloth) ISBN 0-521-83765-0

Denyer SP, Hodges NA, Gorman SP, editors. Hugo and Russell's: pharmaceutical microbiology, 7th ed. Malden (MA): Blackwell; 2004. 481 pp. US\$89.95 ISBN 0632-06467-6
Holland EC, editor. Mouse models of human cancer. Hoboken (NJ): John Wiley and Sons; 2004. 474 pp. US\$195.00 ISBN 0-471-44460-X

McDonald L, editor. Florence nightingale on public health care. Waterloo (ON): Wilfrid Laurier University Press; 2004. 701 pp. \$95.00 (cloth) ISBN 088920-446-2

Packer L, Ong CN, Halliwell B, editors. Herbal and traditional medicine: molecular aspects of health. New York: Marcel Dekker; 2004. 941 pp. US\$195.00 ISBN 0-8247-5436-0

Raphael D, editor. Forward by the Hon. Roy J. Romanow. Social De- terminants of health: Canadian perspectives. Toronto: Canadian Scholars' Press; 2004. 435 pp. \$39.95 ISBN 1-55130-237-3

Runge MS, Ohman EM, editors. Netter's cardiology. Teterboro (NJ): Icon Learning Systems; 2004. 664 pp. US\$79.95 ISBN 1-92900705-1

Simonds C, Warren B. The clown doctor chronicles. New York: Rodopi; 2004. 175 pp. US\$52.00 ISBN 90-420-1079-7

Sweeney G. Clinical pharmacology: a text book for health professionals. CD-ROM included. Available from: www.clinical pharmacologytext.com. 2004. 550 pp. US\$39.98 